\title{
Knowledge levels of and attitudes to organ donation and transplantation among university students
}

\author{
Onur Ozlem Kose ${ }^{1}$, Muhammed Fatih Onsuz ${ }^{2}$, Ahmet Topuzoglu ${ }^{3}$ \\ ${ }^{1}$ Children, Adolescents, Women and Reproductive Health Services Branch, Ministry of Health Istanbul Public Health Directorate, \\ Istanbul, Turkey \\ ${ }^{2}$ Department of Public Health, Osmangazi University Faculty of Medicine, Eskisehir, Turkey \\ ${ }^{3}$ Department of Psychiatry, Dokuz Eylul University Faculty of Medicine, Izmir, Turkey
}

\begin{abstract}
OBJECTIVE: The aim of the present study was to determine knowledge levels and attitudes about organ donation and transplantation among university students.

METHODS: This descriptive study was performed with third-grade students of medicine, pharmacy, and law at a university. Samples weren't selected in the study and it was executed with 145 students who had agreed to participate in the study. The data was collected using a questionnaire of 19 questions. Descriptive statistics were used to analyze the data.
\end{abstract}

RESULTS: $71.7 \%$ of students had positive views about transplantation of their own organs to a suitable recipient, with half of them giving being useful to others as a reason. Among students who had negative views about organ donation, the most important reason given was that it would mean a loss of bodily integrity. $44.1 \%$ of participants had positive views about transplantation of their relatives' organs to another person after death. $51.7 \%$ of participants had positive views about transplantation of the organs of a homeless person to another person after death.

CONCLUSION: Students had generally positive views about organ donation. However; organ transplantation and donation should be included in the students' educational programs in order to increase positive attitudes and organ donations, and transform attitudes into behaviors.

Key words: Attitude; knowledge level; organ donation; transplantation; university students.

$\mathrm{O}$ ne of the important health problems of the human beings is organ failure. Organ transplantation is a process of transferring a healthy and the same duty organ from a living person, a person with established diagnosis of brain death or a dead person. Organ transplantation is a successful treatment method against irreversible vital organ failures as well as being a second life chance for the patients

Received: December 07, 2014 Accepted: January 08, 2015 Online: April 24, 2015

Correspondence: Dr. Muhammed Fatih ONSUZ. Eskisehir Osmangazi Universitesi Tip Fakultesi, Halk Sagligi Anabilim Dali, Meselik Kampusu, 26480 Odunpazari, Eskisehir, Turkey.

Tel: +90 222 - 2392979 e-mail: fatihonsuz@yahoo.com

(c) Copyright 2015 by Istanbul Northern Anatolian Association of Public Hospitals - Available online at www.kuzeyklinikleri.com 
with organ failure $[1,2,3]$. As for organ donation, a person documents and permits with his/her own will that his/her tissues and organs are going to be used for the treatment of other patients after he/ she dies medically [4]. In Turkey, the researches and implementations on organ donation are executed under the Law on Taking, Keeping, Implanting and Transplanting Organs and Tissues enacted in 1979. According to this law, organs can be taken from dead people including newborns to those aged 60 years, and everybody who is over 18 or sane can donate their organs [3].

In Turkey, the organs to be transplanted are generally provided from close relatives of the patient. Similar to Asian and Middle Eastern countries, cadaver organs haven't been donated in sufficient amounts in Turkey and this leads to widening of the gap between the need and procurement of transplantable organs. While approximately $75 \%$ of organ transplantations are performed with the organs taken from healthy people in Turkey, more than $80 \%$ of the transplantations are performed with the organs taken from cadavers in European countries. Organ donations are evaluated according to cadaver donors per one-million populations. While organ donation from cadavers is 20-30 per one million in developed countries, it is 33.6 in Spain, 25.2 in Belgium, 14.1 in Canada, 16.2 in France, 4.5 in Greece, and 2 per million in our country [5]. The most important reason for this is that the society remains insensitive against organ donation. Various studies have obtained the views of people about organ transplantation and showed that academic, and cultural background, socioeconomical level, and religious beliefs are significant factors [6]. In order to increase the frequency of organ donation, knowledge level of the community on this issue should be raised, negative attitudes of the society should be eliminated, and obstacles against organ donation should be overcome. To this end, health personnel and all sections of the society, especially trained ones, should have sufficient knowledge and consciousness $[3,7,8]$.

This study aims to determine knowledge levels and attitudes about organ donation and transplan- tation among third-grade university students in different faculties of a university.

\section{MATERIALS AND METHODS}

This descriptive research was performed in December 2004, with third-grade students in faculties of medicine, pharmacy and law of a university. Any randomized sampling was not done, and the participants were asked to fill the questionnaire forms under surveillance before their classes on a determined day. A total of 150 third-grade students in the faculties of medicine, pharmacy and law were surveyed, and the study was performed with 145 students $(96.6 \%)$ who had accepted to participate in the research. During the survey, a questionnaire form composed of 19 questions and prepared by the researchers was used. This questionnaire form was composed of the questions about socio-demographic characteristics, and knowledge levels and attitudes of the participants about organ transplantation. Approval from the local ethics committee, and necessary permits were obtained from dean's offices of the relevant faculties. Furthermore, the participants were informed about the purpose of the research, and its performers. They were assured about the confidentiality of their personal information, and that their approvals were obtained. The data was evaluated using descriptive statistics in SPSS statistics program.

\section{RESULTS}

Study population consisted of 145 participants (female, $66.2 \%$, and male $53.8 \%$ ). Students were from faculties of law $(31.7 \%)$ medicine $(33.1 \%)$, pharmacy (35.2\%) A total of $4.1 \%$ of the students had a relative who had undergone or had been waiting for organ transplantation, and $9.0 \%$ of them had a relative to whom an organ had been donated. Distribution of some descriptive properties of university students are given in Table 1.

When the participants were asked about their organ donors, they indicated living human donors (92.4\%), cadaver donors (73.1\%), and histocompatible animal donors $(9.6 \%)$. The responders indicat- 
ed kidney (95.9\%), bone marrow (91.0\%), cornea (89.0\%), liver (75.9\%), heart (75.1\%), gall bladder $(6.2 \%)$, and brain $(3.4 \%)$ as transplantable organs. The students indicated that they had obtained their knowledge about organ transplantation from television/radio (81.3\%), newspaper/journals (79.3\%), their environment and friends (28.2\%), books (21.4\%), and internet (15.2\%).

Most $(71.7 \%)$ of the participants stated that they had favourable views about the idea of organ transplantation after death. Half of 104 students emphasized their fovourable views because by donating their organs they would be very helpful for others, and they also stated that in addition to being helpful, they won't need these organs after death $(11.6 \%)$. Other reasons for their favourable views included no more need of their body after death (5.8\%), acquiring merit in God's sight (30.7\%), while $30.7 \%$ gave no reason for their positive views. While $83.7 \%$ of the participants with positive views stated that they wished to donate all of their transplantable organs, and $16.3 \%$ of them wished to donate some of their organs. Only $20.2 \%$ of the students stated that they should apTABLE 1. Distribution of some descriptive characteristics
of university students

\begin{tabular}{lcc} 
Descriptive characteristics & $\mathrm{n}$ & $\%$ \\
\hline $\begin{array}{l}\text { Gender } \\
\quad \text { Women }\end{array}$ & 96 & 66.2 \\
$\quad$ Men & 49 & 33.8 \\
$\begin{array}{l}\text { Faculty } \\
\quad \text { Pharmacy }\end{array}$ & 51 & 35.2 \\
$\quad$ Medicine & 48 & 33.1 \\
$\quad$ Law & 46 & 31.7 \\
Having a relative who had undergone & & \\
or is waiting for organ transplantation & & \\
$\quad$ Yes & 6 & 4.1 \\
$\quad$ No & 139 & 95.9 \\
Having a relative to whom an organ & & \\
had been donated & & \\
$\quad$ Yes & 13 & 9.0 \\
$\quad$ No & 132 & 91.0 \\
Total & 145 & 100.0
\end{tabular}

ply to hospitals and health organizations for organ donation. Only $3.8 \%(n=4)$ of the students with positive views about organ transplantation had a certificate showing that they had donated their organs, and only one of them was always carrying this certificate with him/her. The other 2 students stated that their families weren't aware of their decisions. While, $17.1 \%$ of 41 students with negative views about organ transplantation indicated that their body integrity would be impaired. Some of them $(9.8 \%)$ deemed organ donation to be against their religious beliefs or they thought that it would be a sinful act $(4.9 \%)$ or they would get hurt (2.4\%). While $65.8 \%$ of them gave no reason for their negative views. A little less than half (44.1\%) of the participants had positive views about donating organs of their relatives after their death. A total of 64 students had positive views about organ transplantation because by donating their organs they would be very helpful for others (57.8\%), and also they stated that in addition to being helpful, they won't need these organs after death (7.8\%). Other reasons for their favourable views included no more need of their body after death (5.8\%), acquiring merit in God's sight (30.7\%), while 30.7\% gave no reason for their positive views. A total of 64 students had positive views about organ transplantation because they wanted to help others in need of transplants (57.8\%), and they didn't need their bodies after death $(7.8 \%)$. Acquiring merit in God's sight $(1.5 \%)$ was another rationale. While $24.7 \%$ of them gave no reason for their positive views. Majority $(67.9 \%)$ of 81 students with negative views responded that right to decide didn't belong to them, that they would commit a $\sin (3.7 \%)$, that their body integrity would be impaired $(2.5 \%)$ and that it wasn't true religiously (1.2\%) while $24.7 \%$ of them gave no reason for their negative views. More than half $(51.7 \%)$ of the participants had positive views about transplantation of organs of a deprived person to another one after death. Moreover, $84.1 \%$ of the patients stated that they should make their own decisions about organ transplantation before death, While others responded that their family $(31.0 \%)$ or their physicians $(8.2 \%)$ should make decision for organ donation after 
their death. Knowledge and attitudes of university students about organ transplantation and donation are given in Table 2 .

\section{DISCUSSION}

In the study performed to determine knowledge and attitudes of third-grade students in different faculties of a university about organ donation and transplantation, the students indicated that the most proper donors for organ transplantation were living human donors (92.4\%) followed by cadavers (73.1\%). In investigations performed with the students of several medical faculties in Turkey, cadaver donors were stated as the most proper donors for organ transplantation $[7,9]$. The result of our study is different from literature findings. The reason for this diversity may be that the students from the faculties other than medical faculties were also included in the research. While in European countries cadaveric, and living organ donors consist of $80 \%$, and $20 \%$ of the transplantations performed, in Turkey organ donations are made mainly from living donors (cadaveric donors, $25 \%$ vs living donors, $75 \%$ ). As an outcome of recent studies performed in our country, there has been an increase in the number of cadaveric donors $[10,11]$.

In our research, kidney was stated as the most transplantable organ (95.9\%), followed by bone marrow, cornea, liver, heart, gallbladder and brain. Similarly, kidney is the most known transplantable organ also cited in the literature $[2,7,9,12,13,14]$. This result may lead to the opinion that majority of the patients waiting for organ transplantation are those with renal failure, and this subject creates awareness as it is mentioned in the media more frequently. Furthermore, the first transplanted organ in our country was kidney, and this may have affected the results obtained.

The most important information source of the participants was determined as television/radio, followed by newspaper/journal, environment and friends, books and internet. The result of our research is in parallel with the information in the literature. In both domestic and foreign studies, the most important information sources about organ
TABLE2. Knowledge levels and attitudes of university students about organ transplantation and donation

Knowledge levels and attitudes

$\mathrm{n}$

$\%$

of university students

Donors for organ transplantation*

Living human donor $\quad 134$

92.4

Cadaver donor

Suitable animal donor

14

Transplantable organs*

Kidney

139

Bone marrow

132

Cornea

129

Liver

110

Heart

109

9.6

Gall bladder

9

Brain

5

95.9

91.0

89.0

75.9

75.1

6.2

Information sources about organ

transplantation*

Television/radio

Newspaper/journal

Environment/friend

Books

Internet

15.2

Opinions of the students on

transplantation of their own organs

after death

Positive

Negative

Opinions of the students on

transplantation of their relatives'

organs after death

Positive

64

44.1

Negative

81

55.9

Opinions of the students about

transplantation of a homeless person's

organs after death

Positive

75

51.7

Negative

70

48.3

Decision maker in

organ transplantation*

Their own decisions before death $\quad 122$

Family's decision after death

84.1

Physicians 
transplantation were determined as television/radio, newspaper and journals $[6,15,16,17]$. Today, media and especially television are the most important information sources about health. As television is used widely by the people, it can be shown as the most important information source accessed by the people. It has been stated that the media, especially television, should be used actively in order to inform and direct people about organ donation, and related campaigns $[18,19]$. However; in the studies to be conducted by means of media, negative views about organ donation, and therefore, disinformation and misdirection of the public should be prevented. It has been stated that the organ donation authorities and organizations should be in closer relationships with the media, and non-scientific, misinformative broadcasts and news should be prevented in this way [10].

Majority of the participants $(71.7 \%)$ stated that they approved transplantation of their organs to other people after their death. Half of the students with positive views stated that they approved organ transplantation in order to be useful for others and most of them $(83.7 \%)$ stated that they could donate all of their organs. In a study performed with university students in China, two- third of the students stated that they approved organ donation, and half of the participants had also positive views in this regard in another study $[15,16]$. In the studies performed with a medical faculty students in Italy and Iran, four-fifth of the students stated that they had positive views about organ donation [20, 21]. In the studies performed in our country, the rates of positive views about organ donation varied between $21.0 \%$ and $91.1 \%[6,8,13,22]$. Although rates of positive views about organ donation reported in studies performed with the students of the faculty of health sciences are generally higher than those of our study, results of our study have similarities with those cited both in domestic and foreign literature. The fact that the students in medical faculties have more knowledge about the subject matter may have raised their awareness about this issue and led to these favourable results.

The students who had negative views about organ transplantation didn't desire to impair their body integrity, and thought that donating an organ was a profane act. Commitment of a sin and feeling pain were also indicated $[6,7,13,23]$. In some researches performed in our country, the most important negative reasons about organ donation, and transplantation were stated as personal choice, never thinking about organ transplantation, fear, religious beliefs and lack of trust in physicians [9, 11, 24, 25, 26]. Results similar to our outcomes were also found in the researches performed in other countries. In Europe, the most important reasons asserted against organ donation included abstention from social reaction, being reluctant to impair body integrity, reactions against hospitals and reluctance in decision for organ transplantation $[12,27,28]$. The most important reason for these unfavourable attitudes is lack of knowledge about organ transplantation. Especially, the matters such as never thinking about organ transplantation, personal choice and religious beliefs which stand in the forefront of the studies support this opinion. Raising awareness about this issue is a must in order to make people think about organ donation, and the most important way to do this is to inform the people through education. Furthermore, although they aren't as commonly held as before, religious beliefs entertained against organ donation show lack of knowledge about Islam. Indeed, Islamic religion doesn't prohibit organ donation. Conversely, it is regarded as beneficial for society. The decree (dated 03.03.1980 and \#396/13) issued by Supreme Council of Religious Affairs of Turkish Republic Directorate of Religious Affairs stated that organ transplantation was religiously permissable [29]. All these results show that an education planning is required about organ transplantation which will encompass the entire society

In our study, while nearly half of the students had positive views about transplantation of organs of one of their relatives to another person after their death, half of them approved transplantation of the organs of a deprived person to other people after his/her death. The students with positive views stated that being useful to other people was the most important reason for organ donation. In many researches performed in our country, although not at a higher rate, the students had positive views about transplantation of the organs of their relatives or 
deprived people after their death $[9,11,17]$. These results can be evaluated as that the people aren't very willing to donate the organs of their relatives. The most important reason for this unwillingness is that the relatives are not aware of the importance of organ donation after death, Therefore relatives should take initiatives in this respect as the people cannot be a donor without the approval of their relatives. The most important reason for the people to have negative views about donation of organs of their relatives is that they haven't got the right to decide or they don't want to take initiative, as seen in the results of our study and the other studies [9]. Again in our study, majority of the students $(84.1 \%)$ thought that a person should give his/her own decision about organ donation before his/her death which supports our opinion.

In conclusion, organ transplantation is an important problem in our country as is the case all around the world. While the number of people waiting for organ transplantation is increasing day by day, the number of donated organs is insufficient. It is known that the society should be informed and encouraged to participate in organ donation campaigns in order to increase the number of organ donations. Therefore, arranging campaigns about organ donation and using popular artists, sportsmen and similar people in these campaigns will be significant for informing the society about importance of the subject matter and increasing effectiveness of the campaigns. Furthermore, comprehensive studies should also be performed in order to determine knowledge, opinions, attitudes and negative views of the society in this aspect. Within the framework of these studies, it should be determined, whether or not customs, traditions and beliefs in the society affect organ transplantation and if so to what extent. Involvement of the health personnel in this process shall contribute significantly to the acquisition of comprehensive information. Especially enlightment of the society on these health issues can increase the knowledge level and awareness of the people about organ donation.

Conflict of Interest: No conflict of interest was declared by the authors.
Financial Disclosure: The authors declared that this study has received no financial support.

\section{REFERENCES}

1. Daly BJ. End-of-life decision making, organ donation, and critical care nurses. Crit Care Nurse 2006;26:78-86.

2. Sönmez Y, Zengin E, Ongel K, Kişioğlu N, Oztürk M. Attitude and behavior related to organ donation and affecting factors: a study of last-term students at a university. Transplant Proc 2010;42:1449-52. CrossRef

3. Göz F, Gürelli ŞŞ. The Thoughts of Intensive Care Nurses Toward Organ Donation. Fırat Sağllk Hizmetleri Dergisi 2007;2:77-88

4. Akış M, Katırcı E, Uludağ HY, Küçükkılıç B, Gürbüz T, Türker $\mathrm{Y}$, at al. Knowledge and attitude of Suleyman Demirel Unýversity staff About organ-tissue donation and transplantation. S.D.Ü. Tip Fak Derg 2008;15:28-33.

5. Yaşar M, Oğur R, Uçar M, Göçgeldi E, Yaren H, Tekbaş ÖF, et al. Attitudes of last grade students of a Vocational School of Health about organ donation and related factors with their attitudes. Genel Tip Dergisi 2008;18:33-7.

6 Özer FG, Karamanoğlu AY, Beydağ KD, Fidancıoğlu H, Akıncı E, Şanl 1 I, et al. Effect of Education on a Group of University School for Health Sciences Students' Opinions and Knowledge Level about Organ Transplantation and Donation. Kor Hek 2008;7:39-46.

7 Özmen D, Çetinkaya A, Sarızeybek B, Zeybek A. Knowledge and Views of Students of the Celal Bayar University Manisa School of Health Towards Organ Donation. Türkiye Klinikleri J Med Sci 2008;28:311-8.

8. Kılıç S, Koçak N, Türker T, Gürpınar H, Gülerik D. Attitudes of female university students about organ donation and factors affecting these attitudes. Gulhane Med J 2010;52:36-40.

9. Koçak A, Aktaş EÖ, Şenol E, Kaya A, Bilgin UE. Ege University Faculty of Medicine undergraduates' knowledge level regarding organ donation and transplantation. Ege Tip Dergisi 2010;49:153-60.

10. Okka B, Demireli O. The Public Attitudes towards Organ Donation in Konya. Türkiye Klinikleri J Med Ethics 2008;16:148-58.

11. Aytaş Ö, Kartalcı Ş, Ünal S. Perspectives on Organ Donation in the Context of Sociodemographic Data and Levels of Burn Out in aGroup of Nurse. İnönü Üniversitesi Tip Fakültesi Dergisi 2011;18:26-32.

12. Maroof S, Kiyani N, Zaman Z, Gul RK, Nayyar S, Azmat A, et al. Awareness about organ donation especially kidney donation in Nurpur Shahan, a rural community area in Islamabad, Pakistan. J Pak Med Assoc 2011;61:828-32.

13. Doğan P, Toprak D, Sunal N, Doğan İ. Knowledge, attitude and behaviors of university students on organ transplantation, in Turkey. Smyrna Tip Dergisi 2012;1:16-25.

14. Dutra MM, Bonfim TA, Pereira IS, Figueiredo IC, Dutra AM, 
Lopes AA. Knowledge about transplantation and attitudes toward organ donation: a survey among medical students in northeast Brazil. Transplant Proc 2004;36:818-20. CrossRef

15. Zhang L, Li Y, Zhou J, Miao X, Wang G, Li D, et al. Knowledge and willingness toward living organ donation: a survey of three universities in Changsha, Hunan Province, China. Transplant Proc 2007;39:1303-9. CrossRef

16. Chen JX, Zhang TM, Lim FL, Wu HC, Lei TF, Yeong PK, et al. Current knowledge and attitudes about organ donation and transplantation among Chinese university students. Transplant Proc 2006;38:2761-5. CrossRef

17. Vicdan AK, Peker S, Üçer B. Determination of the Attitudes of Akșehir Health High School Students Concerning Organ Donation. TAF Prev Med Bull 2011;10:175-80. CrossRef

18. Sato H, Akabayashi A, Kai I. Public appraisal of government efforts and participation intend in medico-ethical policymaking in Japan: a large scale national survey concerning brain death and organ transplant. BMC Medical Ethics 2005;6:1. CrossRef

19. Alam AA. Public opinion on organ donation in Saudi Arabia. Saudi J Kidney Dis Transpl 2007;18:54-9.

20. Burra P, De Bona M, Canova D, D'Aloiso MC, Germani G, Rumiati $\mathrm{R}$, et al. Changing attitude to organ donation and transplantation in university students during the years of medical school in Italy. Transplant Proc 2005;37:547-50. CrossRef

21. Sanavi S, Afshar R, Lotfizadeh AR, Davati A. Survey of medical students of Shahed University in Iran about attitude and willingness toward organ transplantation. Transplant Proc
2009;41:1477-9. CrossRef

22. Goz F, Goz M, Erkan M. Knowledge and attitudes of medical, nursing, dentistry and health technician students towards organ donation: a pilot study. J Clin Nurs 2006;15:1371-5. CrossRef

23. Akgün S, Tokalak I, Erdal R. Attitudes and behavior related to organ donation and transplantation: a survey of university students. Transplant Proc 2002;34:2009-11. CrossRef

24. Alat I, Akpinar MB, Eğri M, Aydin N, Aydemir IK, Aldemir M, et al. The conviction of patients and hospital attendants on tissue and organ transplantation. [Article in Turkish] Anadolu Kardiyol Derg 2007;7:316-7.

25. Keçecioğlu N, Tuncer M, Yücetin L, Akaydin M, Yakupoğlu G. Attitudes of religious people in Turkey regarding organ donation and transplantation. Transplant Proc 2000;32:629-30. CrossRef

26. Naçar M, Çetinkaya F, Kanyılmaz D, Tokgöz B, Utaş C. The Attıtudes Of Medical Students To Organ Donation. Turk Neph Dial Transpl 2001;10:123-8.

27. Chung CK, Ng CW, Li JY, Sum KC, Man AH, Chan SP, et al. Attitudes, knowledge, and actions with regard to organ donation among Hong Kong medical students. Hong Kong Med J $2008 ; 14: 278-85$.

28. Schütt GR. 25 years of organ donation: European initiatives to increase organ donation. Transplant Proc 2002;34:2005-6. CrossRef

29. Organ nakli, 396 sayılı karar. Türkiye Cumhuriyeti Başbakanlık Diyanet İşleri Başkanlığı, Din İşleri Yüksek Kurulu, 1980. Available at: http://www.diyanet.gov.tr/dinisleriyuksekkurulu/sayfalar/organnakli.aspx Accessed August 06, 2013. 